\title{
Meningkatkan Imunitas Tubuh Melalui Senam Umum Ditengah Pandemi Covid-19
}

\author{
Iman Rubiana, Fegie Rizkia Mulyana, Melya Nur Herliana, Novi Soraya \\ Universitas Siliwangi \\ Email: imanrubiana@unsil.ac.id
}

\begin{abstract}
Abstrak
Tujuan pengabdian ini memberikan edukasi yang dilakukan secara praktek mengenai pentingnya melakukan aktivitas fisik dalam menjaga imunitas tubuh pada masa pandemic covid-19. Karena dampak dari pandemi diberlakukannya physical distancing dan berbagai aktifitas baik sosial ataupun pekerjaan dianjurkan untuk bekerja dari rumah atau dengan istilah work from home (WFH). Dengan adanya batasanbatasan serta tekanan keadaan yang merubah semua tatanan kehidupan berakibat pada pola pikir dan tingkat imunitas seseorang. Pelaksanaan pengabdian melakukan aktivitas olahraga kebugaran berupa senam umum yang dilakukan setiap hari minggu pagi oleh intrukstur profesional. Dengan senam umum diharapkan Imunitas warga akan meningkat, Disamping mengajak berolahraga senam umum, tim pengabdian pun memberikan edukasi terkait cara berolahraga yang baik dan benar sesuai Frekuensi, Intensitas, Time dan Tipe (FITT). Selain itu tim pengabdian memberikan pemahaman kepada warga terkait pandemi agar masyarakat mempunyai perilaku dan kebiasaan sehari-harinya untuk bisa menjaga protokol kesehatan.
\end{abstract}

Kata Kunci: Pandemi, senam umum, Protokol Kesehatan

\begin{abstract}
The purpose of this service is to provide education that is carried out in practice about the importance of doing physical activity in maintaining body immunity during the Covid-19 pandemic. Due to the impact of the pandemic, the implementation of physical distancing and various activities, both social and work, is recommended to work from home or in the term work from home (WFH). With the limitations and pressures of circumstances that change all the orders of life, it affects one's mindset and level of immunity. The implementation of the service is doing fitness sports activities in the form of general exercises which are carried out every Sunday morning by professional instructors. With general exercise, it is expected that the immunity of residents will increase. Besides inviting general exercise, the service team also provides education regarding how to exercise properly and correctly according to Frequency, Intensity, Time and Type (FITT). In addition, the community service team provides understanding to residents related to the pandemic so that people have daily behavior and habits to be able to maintain health protocols.
\end{abstract}

Keywords: Pandemic, general exercise, Health Protocol

\section{PENDAHULUAN}

Covid-19 adalah penyakit yang disebabkan oleh infeksi virus SARS-CoV-2, pertama kali diidentifikasi di kota Wuhan, di provinsi Hubei Cina pada Desember 2019. Menurut Ketua WHO, Tedros Adhanom Ghebreyesus dalam suatu pertemuan di Jenewa "Covid-19" merupakan singkatan dari 'Co' yang artinya 'Corona', 'Vi' yaitu 'virus', dan "d" untuk 'disease' artinya penyakit, sedangkan "19" adalah tahun penemuannya di Kota Wuhan, Cina, pada 31 Desember 2019. Covid-19 sebelumnya dikenal sebagai Novel 201 Novel Coronavirus (2019$\mathrm{nCoV}$ ) penyakit pernapasan, sebelum Organisasi Kesehatan Dunia (WHO) menyatakan nama resmi sebagai Covid-19 pada bulan Februari 2020. (BANGKAPOS.COM, 2020). World Health Organization (WHO) telah menilai wabah ini sepanjang waktu dengan tingkat penyebaran dan keparahan yang mengkhawatirkan, dan oleh tingkat tidak adanya tindakan yang 
mengkhawatirkan. Oleh karena itu kami telah membuat penilaian bahwa COVID-19 dapat dikategorikan sebagai pandemi. Pandemi bukanlah kata untuk digunakan dengan ringan atau sembrono. Ini adalah kata yang, jika disalahgunakan, dapat menyebabkan ketakutan yang tidak masuk akal, atau penerimaan yang tidak dapat dibenarkan bahwa pertarungan telah berakhir, yang mengarah pada penderitaan dan kematian yang tidak perlu. (WHO Director-General, 2020).

Menurut Kamus Besar Bahasa Indonesia (KBBI) Istilah pandemi dimaknai sebagai wabah yang berjangkit serempak di mana-mana, meliputi daerah geografi yang luas. Dalam pengertian yang paling klasik, ketika sebuah epidemi menyebar ke beberapa negara atau wilayah dunia. Wabah penyakit yang masuk dalam kategori pandemi adalah penyakit yang menular dan memiliki garis infeksi berkelanjutan.( Lipsitch, 2020). Jadi, jika ada kasus terjadi di beberapa negara lainnya selain negara asal, tetap digolongkan sebagai pandemi. Menjelaskan situasi sebagai pandemi tidak mengubah penilaian WHO terhadap ancaman yang ditimbulkan oleh virus ini. Itu tidak mengubah apa yang dilakukan WHO, dan itu tidak mengubah apa yang harus dilakukan oleh negara.

Virus yang menyebabkan COVID-19 menginfeksi orang-orang dari segala usia. Namun, bukti sampai saat ini menunjukkan bahwa terdapat dua kelompok orang berisiko lebih tinggi terkena penyakit COVID-19 yang parah. Ini adalah orang yang lebih tua (yaitu orang di atas 60 tahun) dan mereka yang memiliki kondisi medis yang mendasarinya (seperti penyakit kardiovaskular, diabetes, pernapasan kronis dan kanker). Risiko penyakit parah secara bertahap meningkat dengan usia mulai dari sekitar 40 tahun. Sangat penting bahwa orang dewasa dalam kisaran usia ini melindungi diri mereka sendiri dan pada gilirannya melindungi orang lain yang mungkin lebih rentan. WHO telah mengeluarkan saran untuk dua kelompok ini dan untuk dukungan masyarakat untuk memastikan bahwa mereka dilindungi. COVID-19 tanpa terisolasi, distigmatisasi, dibiarkan dalam posisi peningkatan kerentanan atau tidak dapat mengakses dasar ketentuan dan kepedulian sosial. Nasihat ini mencakup pokok penerimaan pengunjung, perencanaan persediaan obat-obatan dan makanan, keluar dengan aman di tempat umum dan tetap terhubung dengan orang lain melalui panggilan telepon atau cara lain. Ini penting bahwa kelompok-kelompok ini didukung oleh komunitas mereka selama wabah COVID-19.

Virus corona alias Covid-19 adalah virus yang menyerang sistem pernapasan manusia. Virus corona masih satu 'kerabat' dengan penyebab SARS dan MERS yang sempat merebak beberapa tahun lalu. Namun, kuat dugaan Covid-9 berasal dari kelelawar dan ular berjenis krait dan kobra. Virus dapat berpindah dari hewan ke manusia yang berada dalam satu area sama. Virus corona ini tergolong sadis karena dapat mematikan atau dapat menyebabkan luka permanen pada paru-paru pasien yang sudah terinfeksi dan sembuh. Secara umum bila ada yang mengalami demam, flu, batuk, dan sesak napas dalam batas waktu tertentu ini adalah suatu gejala penyakit Covid-19, maka harus ada kewaspadaan dan kerja sama yang baik dengan keluarga atau rekan kerja selama beraktivitas di dalam rumah, di ruang kerja, dan di dalam lingkungan masyarakat. Kemudian, menurut WHO, virus itu menular dari manusia satu ke manusia lain. Cara penularannya, virus Covid-19 menyebar melalui tetesan air liur atau keluar dari hidung ketika orang yang terinfeksi sedang batuk atau bersin. Tetesan tersebut mendarat di mulut atau hidung orang yang berada di dekatnya. Virus corona juga bisa menular antara orang yang saling bersentuhan dalam jarak sekitar $30 \mathrm{~cm}$. Orang sehat ini lantas menyentuh mata, mulut, atau hidung mereka. Lantas, tetesan yang mengandung virus corona terhirup ke dalam paru-paru. Sehingga menyebabkan orang tersebut ikut tertular virus corona. Hingga kemudian ia menulari orang lain lagi bila tak segera mengisolasi diri atau melakukan langkah pencegahan. Selain itu, virus corona dapat mendarat di permukaan benda yang disentuh oleh orang sehat. Namun, hal ini tidak dianggap sebagai cara utama virus corona menyebar. Orang yang 
terjangkit virus corona biasanya menunjukkan sejumlah gejala. Misal demam, batuk, dan sesak napas dalam rentang waktu selama 14 hari. Penyakit coronavirus (Covid-19) adalah penyakit menular yang disebabkan oleh virus baru. Penyakit ini menyebabkan penyakit pernapasan (seperti flu) dengan gejala seperti batuk, demam, dan dalam kasus yang lebih parah, kesulitan bernafas. Anda dapat melindungi diri dengan sering mencuci tangan, menghindari menyentuh wajah, dan menghindari kontak dekat (1 meter atau 3 kaki) dengan orang-orang yang tidak sehat.

Pemahaman, kesadaran, dan kedisiplinan warga terkait bahaya pandemi ini masih sangatlah minim, bisa terlihat dari perilaku setiap warga serta kebiasaan sehari-harinya. Situasi ini sama halnya dialami juga oleh warga Kelurahan Cibogor RW 014, yang terletak di Jl. Moch Hatta-Cibogor, Sukamanah, Cipedes Tasikmalaya. Permasalahan mitra ini didapat dari wawancara yang dilakukan oleh tim pengabdian PbM-SK kepada ketua RW dan beberapa warga kedua mitra tersebut. Hasil dari wawancara tersebut didapat sebuah informasi dan harapan dari masing-masing ketua RW untuk dapat diberikan penyuluhan kepada warga dari instansi/lembaga terkait. Sehingga tim pengabdian PbM-SK Pendidikan Jasmani menyimpulkan dan merencanakan perlakuan kepada para warga perum Bumi Citra Saguling dan warga kelurahan Cibogor RW 014 berupa luaran dan jasa. Luaran dalam pengabdian ini berupa pemberian langsung peralatan dan fasilitas kesehatan seperti masker wajah, handsanitizer, Thermometer Gun Infrared. Adapun luaran lainnya berupa jasa yaitu dengan memberikan edukasi dan pemahaman tentang cara menjaga imunitas tubuh ditengah pandemi Covid-19 dengan langsung mengajak warga untuk berolahrga senam masal bersama tim pengabdian PbM-SK. Selaras dengan istilah imunitas diatas, (Giriwijoyo 2012) menyatakan "kesegaran jasmani adalah derajat sehat dinamis seseorang yang menjadi kemampuan jasmani dasar untuk dapat melaksanakan tugas yang harus dilaksanakan". Selain dari pengertian tersebut, (Ambarukmi, 2008) menyatakan "kesegaran jasmani adalah taraf kemampuan dan ketahanan kerja seseorang dalam melakukan suatu tugas dalam waktu relatif lama tanpa menimbulkan kelelahan yang berarti". Kesegaran jasmani didefinisikan pula sebagai kemampuan tubuh seseorang untuk melakukan tugas pekerjaan sehari-hari tanpa menimbulkan kelelahan yang berarti. (Depdiknas,2002). Maksud dari tugas atau pekerjaan yang dilakukan sehari-hari seperti aktivitas fisik atau pekerjaan baik yang dilakukan sehari-hari ataupun aktivitas olahraga ringan maupun berat. Aktivitas latihan fisik ringan lebih bermanfaat pada fungsi imunitas bila dibanding hanya melakukan aktivitas berupa duduk/tidak melakukan kegiatan apapun. Kekebalan tubuh dapat mudah ditingkatkan dengan melakukan latihan fisik/olahraga juga istirahat serta tidur cukup.

Aktivitas olahraga yang dapat meningkatkan imun tubuh atau kesegaran jasmani adalah olahraga yang cukup memberikan beban kepada jantung dan paru. Aktivitas latihan fisik ringan lebih bermanfaat pada fungsi imunitas bila dibanding hanya melakukan aktivitas berupa duduk/tidak melakukan kegiatan apapun. Kekebalan tubuh dapat mudah ditingkatkan dengan melakukan latihan fisik/olahraga juga istirahat serta tidur cukup. Mekanisme kenaikan atau penurunan imun saat latihan fisik/olahraga dapat memberikan manfaat positif bagi kesehatan dalam jangka panjang, hal ini berkaitan dengan pertahanan tubuh terhadap infeksi penyakit. (Sukendra, 2015).

Sistem imunitas (immune system) adalah sistem pertahanan alamiah tubuh untuk melawan (organisme) patogen. Organisme patogen yaitu organisme yang dapat menimbulkan penyakit pada manusia: Cacing parasit, protozoa, fungi, bakteria, dan virus. (Harlan, 2018). System ini terdiri dari dua jenis yaitu; (1) system imunitas bawaan, Merupakan lini pertahanan pertama terhadap patogen. Ciri sistem imunitas bawaan respons terbentuk cepat, respons selalu sama, tak bersifat spesifik-antigen, pajanan (exposure) berulang terhadap antigen yang sama 
tak meningkatkan respons. Sistem imunitas bawaan terdiri atas komponen selular yaitu fagosit dan komponen kimiawi yaitu komplemen. (2) System imunitas adaptif, merupakan sistem imunitas spesifik atau reaksi pertahanan tubuh yang disesuaikan/diadaptasikan terhadap karakteristik antigen.

Adapun jenis olahraga yang dipilih dalam pengabdian ini adalah olahraga yang sifatnya aerobik, di antaranya senam aerobik. Senam aerobik merupakan suatu sistematika gabungan antara rangkaian gerak dan musik yang disengaja dibuat sehingga muncul keselarasan antara gerakan dan musik tersebut untuk mencapai tujuan tersebut (Indrawathi, 2015). Selaras dengan pendapat Indrawathi, (Susanti, Syafe'l, 2017) menyebutkan latihan senam aerobik merupakan latihan yang menggerakkan seluruh bagian tubuh dengan gerakan yang terus-menerus, berirama, maju dan berkelanjutan. Dalam senam aerobik biasanya dipilih gerakan yang mudah, menyenangkan dan bervariasi. intensitas senam yang diberikan kepada warga yaitu senam aerobic low impact karena kebanyakan dari penduduk setempat kisaran umur 35 tahun ke atas.

\section{BAHAN DAN METODE}

Langkah yang akan ditempuh melakukan Program Pengabdian bagi Masyarakat- Skema Kesehatan (PbM-SK) ini sebagai berikut:

1. Menindaklanjuti kerjasama antara Universitas Siliwangi dengan pengurus RT dan RW Perum Bumi Citra Saguling dan Kampung Cibogor RW 014.

2. Melakukan koordinasi dengan Ketua RT/RW Perum Bumi Citra Saguling dan Kampung Cibogor RW 014.

3. Menyiapkan peralatan dan mengkonsep kegiatan untuk pelaksanaan Program Pengabdian bagi Masyarakat- Skema Kesehatan (PbM-SK).

4. Menentukan jadwal dan acara pertemuan.

5. Menentukan waktu, tempat pelaksanaan serta teknis kegiatan dengan menjalankan protokol kesehatan.

Berikut rangkaian kegiatan Program Pengabdian bagi Masyarakat-Skema Kesehatan (PbMSK) :

- Melakukan kegiatan sosialisasi dengan fokus bahasan teknis kegiatan

- Melakukan kegiatan sebanyak 8 pertemuan di Perum Bumi Citra Saguling, dan 8 pertemuan di Kelurahan Cibogor RW 014.

- Teknis kegiatan diawali dengan pembukaan PbM-SK antara tim pengabdian, pengurus $\mathrm{RT} / \mathrm{RW}$ beserta warga setempat serta memberikan penyuluhan dan edukasi terkait pandemi dan budaya hidup sehat dan bersih.

- Penyerahan secara langsung alat dan fasilitas kesehatan kepada warga untuk dipakai setiap pertemuan

- Melaksanakan senam massal bersama warga setempat sebanyak 8 pertemuan. Setiap pertemuan selau dicek denyut nadi awal dan setelah selesai berolahraga.

- Melakukan wawancara kepada RW setempat terkait tanggapan, masukan, kesan, dan pesan selama melakukan pengabdian skema kesehatan ini.

\section{HASIL YANG DICAPAI}

Melalui program pengabdian bagi masyarakat sesuai tujuan yang direncanakan yaitu berangkat dari permasalahan warga dan situasi yang tengah dihadapi terkait pandemi covid-19, melalui pemberian alat kesehatan berupa masker, handsanitizer dan thermometer gun infrared dalam kegiatan senam bersama dan penyampaian penyuluhan serta edukasi kepada warga terkait cara berolahraga yang baik dan benar adapun hasil yang dicapai yaitu, dengan 
difasilitasinya dalam rangkaian pengabdian ini, motivasi masyarakat untuk berolahraga terdorong dan antusias yang luar biasa, bahkan dari jajaran pengurus rukun warga (RW) dan karang taruna. Semua lapisan berpartisipasi dalam rangkaian acara yang tim pengabdian lakukan. Bukti meningkatnya motivasi dilihat dari kesiapan dan animo warga ketika mengikuti senam massal. Secara kuantitas jumah peserta yang berpartisipasi di setiap pertemuan atau setiap minggunya selalu bertambah.

Selain meningkatnya motivasi, bertambahnya pemahaman serta pengetahuan bagi warga yang sama sekali belum mengetahui bagaimana cara berolahraga yang baik dan benar menurut prinsip frekuensi, intensitas, time, dan tipe (FITT). Hal ini ditunjukkan dengan masyarakat mampu mengaplikasikan materi yang disampaikan tim pengabdian disetiap pertemuan yaitu mengecek denyut nadi awal dan sesudah berolahraga dengan di pimpin oleh para instruktur serta mengetahui batas bawah dan atas denyut nadi masing-masing sesuai rumus denyut nadi maksimal (DNM).

Dengan memberikan tauladan serta himbauan disetiap pertemuannya kepada masyarakat, yaitu berolahraga dengan mematuhi protokol kesehatan serta menerapkan budaya hidup bersih dan sehat warga pun terbiasa dan lebih disiplin memperhatikan protokol kesehatan. Hal ini ditunjukkan dengan kekonsistenan warga disetiap pertemuannya selalu mengenakan masker dan cek suhu tubuh serta mencuci tangan tanpa kontak berlebihan dengan peserta lain.

\section{PEMBAHASAN}

Setelah memberikan pengabdian melalui senam umum ke warga masing-masing warga perum merasakan hal positif seperti terjalinnya keakraban dan kebersamaan sesama warga dan terlihat antusias dalam berolahraga. Dampak positif dari setiap pertemuan pengabdian melalui senam umum, meningkatnya imunitas tubuh hal ini dilihat dari aktivitas warga yang selalu dilakukan setiap hari semakin meningkta, antusias warga setiap pertumuan menjadi semakin banyak mungkin dikarenakan pengabdian ini dirasakan memberikan dampak positif terhadap dirinya. Warga menjadi tahu berolahraga yang baik dan benar sesuai kebutuhan dan usia mereka masing-masing. Setiap pertemuan tim pengabdian memberikan pemahaman mengenai pentingnya menjaga imunitas tubuh dengan cara berolahraga yang mana warga di berikan teori cara berolahraga dengan baik melalui perhitungan tentang denyut nadi maksimal (DNM) serta rentang zona latihan (training zone). Adapun pengertian training zone menurut Rosynelli (2009:5) dalam (Indrawathi, 2015) yaitu "daerah ideal denyut nadi dalam fase latihan, rentang training zone adalah 60\%-90\% dari denyut nadi maksimal seseorang." Adapun empat zona latihan berdasarkan detak jantung. Setelah semua warga diberikan pemahaman tentang bagaimana cara menghitung DNM (denyut nadi maksimal) dan mengetahui bagaimana tolak ukur aktivitas fisik yang baik dan benar untuk dilakukan serta tidak berbahaya bagi kesehatan dan kondisi masing-masing individu, akhirnya seluruh warga bisa mengaplikasikan teori tersebut dalam aktivitas sehari-hari serta memahami kebutuhan intensitas olahraga minimal untuk pribadinya sendiri dan pemahaman mengenai menjaga protokol kesehatan pada masa pandemi.

\section{KESIMPULAN DAN SARAN}

Tujuan dari pengabdian yang dilaksanakan ini yaitu untuk meningkatkan imunitas tubuh masyarakat melalui olahraga senam ditengah pandemi covid-19 yang dilaksanakan secara rutin setlap minggunya. Melihat dan menganalisis kebutuhan serta permasalahan yang terjadi di masyarakat khususnya masyarakat perumahan perum bumi citra saguling sebagai mitra ke-1, RW 014 kampung cibogor kelurahan sukamanah, kecamatan cipedes sebagai mitra ke-2, tim pengabdian menyimpulkan apa yang tepat untuk diberikan kepada masyarakat yaitu berupa jasa (memberikan senam bersama) dan wawasan tentang cara berolahraga sekaligus penyerahan 
bantuan alat kesehatan seperti masker, handsanitizer, dan thermometer gun infrared sesuai dengan prosedur Pengabdian bagi Masyarakat Skema Kesehatan (PbM-SK) 2020. Adapun hasil dari pengabdian ini yaitu warga perum lebih termotivasi untuk melakukan aktivitas senam, merasakan manfaat dari kegiatan tersebut seperti bisa menjalin silaturahmi antar RT dan antar warga lainnya, serta mengetahui apa saja yang harus disiapkan ketika akan melakukan aktivitas senam. Tim pengabdian selama pertemuan berlangsung selalu memberikan teori dan pengetahuan tentang denyut nadi maksimal (DNM) serta memberikan pemahaman tentang training zone atau zona latihan, serta memberikan edukasi terkait budaya hidup sehat dimasa pandemi dan jenis olahraga apa saja yang sesuai dengan kebutuhan serta usia masing-masing. Hasil dari edukasi tersebut warga memiliki pengetahuan dan pemahaman tentang bagaimana cara berolahraga yang baik dan benar dengan memperhatikan frekuensi, intensitas, time, dan tipe (FITT).

Selain itu masyarakat memahami terkait zona latihan sesuai dengan tipe olahraga (olahraga rekreasi) dan kalangan usia mereka masing-masing. Dengan adanya program pengabdian bagi masyarakat skema kesehatan, antusias dan motivasi warga dalam berolahraga sangatlah tinggi, hal ini dibuktikan dengan adanya permintaan dari masing-masing mitra untuk tetap berlanjut melakukan rutinitas senam seperti yang dilakukan oleh tim pengabdian. Dengan meningkatknya motivasi dalam berolahraga, akan berbanding lurus dengan meningkatnya imun tubuh, karena setiap hal yang dilakukan dengan kesadaran dan diiringi dengan kesenangan akan menghasilkan hormon endorfin yang berperan sebagai penghilang stress, menimbulkan rasa bahagia, dan menjaga kekebalan tubuh. (Putera, 2020).

Kalangan masyarakat baik perumahan ataupun masyarakat umum dianjurkan menyempatkan minimal dalam satu minggu tiga kali untuk melakukan aktivitas olahraga, idealnya 3-5 kali dalam seminggu untuk tetap menjaga kebugaran tubuh. Manfaat yang dirasakan ketika memiliki tubuh yang bugar yaitu mampu beraktivitas dan mengerjakan sesuatu tanpa mengalami kelelahan yang berarti dan tubuh secara cepat mampu melakukan pemulihan kembali. Disarankan bagi masyarakat untuk cerdas dalam memilih jenis olahraga, intensitas olahraga yang dilakukan agar sesuai dengan kebutuhan serta kemampuan tubuh kita. Usahakan dengan hati yang senang dan tidak ada unsur keterpaksaan ketika melakukan olahraga, karena disamping menyehatkan, olahraga merupakan salah satu cara untuk menghasilkan atau memproduksi hormon endorfin yaitu hormon yang bisa menghilangkan stress, mengikis rasa sakit dan tidak nyaman serta membangkitkan energi positif dalam tubuh sehingga kekebalan tubuh pun meningkat. Perhatikan intensitas dan waktu ketika melakukan olahraga, dengan bertolak ukur pada denyut nadi maksimal (DNM), intensitas untuk olahraga rekreasi ada pada kisaran 65\%-75\% dari denyut nadi maksimal (DNM) serta waktu yang dianjurkan untuk berolahraga yaitu sekitar 30-45 menit. Dengan mengetahui tata cara berolahraga yang baik dan benar, akan memberikan pengaruh yang positif terhadap peningkatan derajat kebugaran masyarakat khususnya melalui olahraga senam massal. Manfaat yang lain yaitu masyarakat menyadari pentingnya untuk tetap berbudaya hidup bersih dan sehat ditengah pandemi covid19.

\section{DAFTAR PUSTAKA}

Ambarukmi, Hatmisari, D. (2008). Pedoman dan Materi Pelatih Tingkat Dasar. Jakarta : Deputi Bidang Peningkatan Prestasi dan IPTEK Olahraga Kementerian Negara Pemuda dan Olahraga Republik Indonesia.

Depdiknas. (2002). Tingkat Kesegaran Jasmani Anda. Jakarta : Pusat Pengembangan Kualitas Jasmani. 
Giriwijoyo, S. \& Sidik, Zafar. (2012). Ilmu Faal Olahraga (fisiologi olahraga). Bandung : PT Remaja Rosdakarya.

Harlan, Johan. 2018. Biopsikologi. Depok: Gunadarma

Indrawathi, Ni Luh Putu. 2015. Perbedaan Pengaruh Latihan Senam Aerobik Low Impact Dan Mix Impact Terhadap Tingkat Kesegaran Jasmani Pada Mahasiswa Fakultas Pendidikan Olahraga Dan Kesehatan (FPOK) IKIP PGRI Bali Tahun Pelajaran 2015. Jurnal Pendidikan Kesehatan Rekreasi : Volume 2 : Hal. 70 - 80, Desember 2015.

Marc Lipsitch, D. Phil., at al. 2020. Defining the Epidemiology of Covid-19 — Studies Needed. The New England Journal of Medicine; Massachusetts Medical Society.

Prativi, Gilang Okta, dkk. 2013. "Pengaruh Aktivitas Olahraga Terhadap Kebugaran Jasmani”. JSSF : Volume 2, Nomor 3. http://journal.unnes.ac.id/sju/index.php/jssf

Putera, Arif. 2020. Mengenal Endorfin, Salah Satu Senyawa Kebahagiaan. https://www.sehatq.com/artikel/hormon-endorfin-adalah-salah-satu-senyawakebahagiaan-di-tubuh

Sukendra, DM. 2015. Efek Olahraga Ringan pada Fungsi Imunitas terhadap Mikroba Patogen :Infeksi Virus Dengue. Sport Science Journa : Volume 5, No. 2. https://journal.unnes.ac.id/nju/index.php/miki/article/view/7890. https://doi.org/10.15294/miki.v5i2.7890

Surat Edaran No. 6.11.1/MENPORA/VI/2020

Susanti, E., Syafe'l, M.M. 2017. Seminar Kepelatihan Pelatih Senam Aerobik se-Kabupaten Karawang. SENADIMAS. LPPM Undiksa. ISBN : 978-602-6428-12-7

Yasirin, Ahmad., dkk. 2014. "Latihan Senam Aerobik dan Peningkatan Limfosit CD4 (Kekebalan Tubuh) pada Penderita HIV". Volume $3, \quad$ No. 3. http://journal.unnes.ac.id/sju/index.php/jssf

World Health Organization. Coronavirus disease 2019 (COVID-19) Situation Report - 51. Data as reported by national authorities by 10 AM CET 11 March 2020. 


\section{LAMPIRAN}
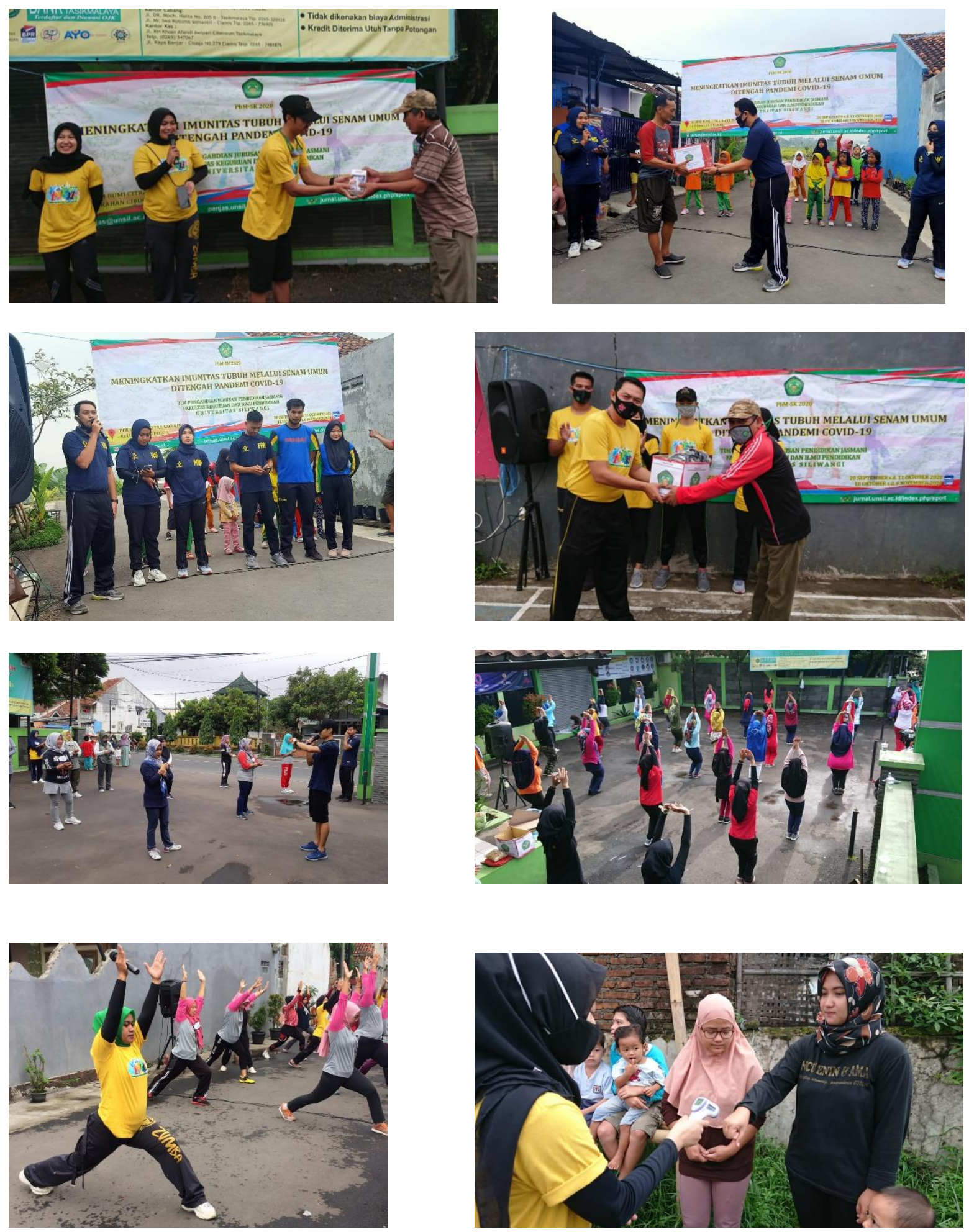

Gambar 1. Pelaksanaan Senam Umum dan Pembagian Alat Kesehatan 